\title{
GREEN CONSUMERISM: CATALYST FOR ENVIRONMENTAL MARKETING
}

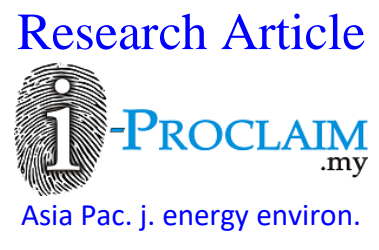

\section{Prabir Chandra Padhy ${ }^{1 *}$, Ashiss Kumar Mishra ${ }^{2}$}

${ }^{1}$ Assistant Professor (Management), Shroff S R Rotary Institute of Chemical Technology (SRICT), Vataria, Guajarat, INDIA

${ }^{2}$ Corporate Advisor and Director, Hitech Group, Bhubaneswar, Odisha, INDIA

*Email for Correspondence: prabirchandrapadhy@yahoo.co.in

Abstract

In 21st century race towards industrialization is fast \& furious. Due to the Industrial movements natural environment is heavily influenced. Environmental marketing is one best possible way to protect the environment. Both the organizations \& consumers have changed their mind to address this issue. Green consumerism has taken the role of catalyst for environmental marketing. Aim of this paper to analyze the consumer behavior towards environmental marketing. This article also establishes the relationship between consumer behavior and purchasing decision of the customer on the green marketing ground. This research paper highlights the cause behind environmental marketing along with the initiative taken by the industries to promote environmental marketing.

Key words

Consumer behavior, environmental marketing, green consumerism, industrial movements, purchasing decision

\section{INTRODUCTION:}

Due to ' $\mathrm{N}$ ' number of causes including global warming, environmental pollution the whole world is now motivating the entrepreneurs to practice and implement the tagline of "GO GREEN" in their business. It has also been found in various researches conducted by the environmental experts that the awareness of the customers towards eco-friendly products is being increased day by day gradually. Organizations also take steps towards green marketing not only due to the awareness \& approach of the consumer towards environment-friendly products but also they consider it as their social responsibility.

\section{OBJectives:}

- To analyze the consumer behavior towards environmental marketing regarding marketing mix

- To examine the factors of consumer purchasing decisions regarding brand value \& availability of the product.

- To establish the relationships between consumer behavior and consumer purchasing decisions.

\section{Research Methodology:}

Consumer behavior towards environmental marketing was calculated regarding marketing mix components, i.e., product, price, place \& promotion. Purchasing decisions of customers was calculated in terms of four aspects- i.e., high brand value, low band value, widely available \& not widely available- of the product with respect to the environment friendly aspects of the products. Data collected from 200 individuals by the help of questionnaires on a seven-point Likert-type scale and their classification also made. Among them 128 males were there\& 72 females were there. More than half of the respondent $(52 \%)$ was from young professionals i.e., 25 to 35 years. A larger mass of the respondent (48\%) was belonged to middle class families.

\section{Chart-I}

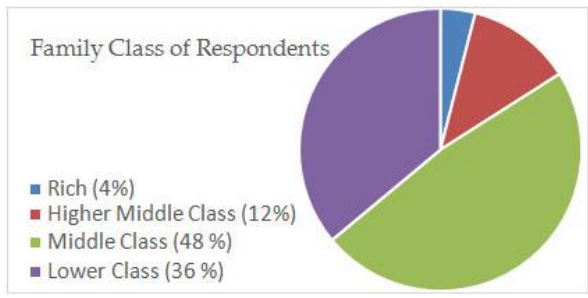


FINDINGS

\section{Consumer behavior towards Environmental Marketing}

Consumer behavior towards environmental marketing was calculated regarding marketing mix components, i.e., Product, Price, Place and Promotion. The outcome gained from the survey is mentioned in table- I

Table I: Consumer behavior towards Environmental Marketing

\begin{tabular}{|l|l|c|c|c|c|c|c|}
\hline $\mathbf{S 1}$ & $\begin{array}{l}\text { Components of Marketing } \\
\text { Mix- Environmental Marketing }\end{array}$ & $\begin{array}{c}\text { Favor } \\
\mathbf{( \%} \text { age })\end{array}$ & $\begin{array}{c}\text { Neutral } \\
\mathbf{( \%} \text { age })\end{array}$ & $\begin{array}{c}\text { Against } \\
\text { (\% age })\end{array}$ & $\begin{array}{c}\text { Mean } \\
\text { Standard } \\
\text { Deviation }\end{array}$ & $\begin{array}{c}\text { Standard } \\
\text { Error }\end{array}$ \\
\hline $\mathbf{1}$ & Product: Priority to eco-friendly products & 92 & 5 & 3 & 6.63 & 1.09 & .07 \\
\hline $\mathbf{2}$ & $\begin{array}{l}\text { Price: Willingness to purchase Green products at } \\
\text { more price }\end{array}$ & 88 & 5 & 7 & 6.4 & 1.5 & .097 \\
\hline $\mathbf{3}$ & $\begin{array}{l}\text { Place: Choose those places which are } \\
\text { environmental friendly }\end{array}$ & 76 & 5 & 19 & 5.47 & 2.3 & 1.49 \\
\hline $\mathbf{4}$ & $\begin{array}{l}\text { Promotion: Prefer promotion campaign that } \\
\text { protect environment }\end{array}$ & 80 & 6 & 14 & 5.7 & 2.12 & .137 \\
\hline
\end{tabular}

\section{Environmental Marketing Mix}

Environmental marketing mix consists of four components.

Product: Organization must produce the environment-friendly products that not only reduce the pollutant from the environment but also protect the environment. Eco-friendly products always save the natural resources. Therefore, awareness is created among the consumer to purchase the green products. All most all consumers (92\%) give their opinion in favor of the green products with standard deviation 1.09 .

Price: The cost of environment-friendly products is a little bit more than the traditional substitute products. Environmental costing decisions always take into consideration the people, planet \& profit in such a way that it in turn takes care of the health of stakeholders \& society. $88 \%$ respondents showed their willingness to purchase the green products at more price with standard deviation 1.5

Place: Green place is about dealing logistics to reduce the conveyance emissions thereby in effect aiming at dropping the carbon footprint. $76 \%$ consumers are given their opinions for green place with standard deviation $2.3 \%$

Promotion: A communication with the market should put stress on environmental aspects. $80 \%$ consumers prefer promotion campaign that is environment friendly with standard deviation 2.12.

\section{Purchasing Decisions of Customers}

Purchasing decisions of customers were calculated in terms of four aspects i.e., high brand value, low band value, widely available \& not widely available of the product with respect to the environment friendly aspects of the products.

The outcome gained from the survey is mentioned in table- II

- $74 \%$ consumers showed their willingness to purchase low brand value products which possess eco-friendly characteristics with standard deviation 2.1

- $70 \%$ of the consumers give their opinion in favor of high brand value products but not having eco-friendly characteristics with standard deviation 2.45

- $88 \%$ consumers preferred to purchase eco-friendly products which is not even widely available with standard deviation 1.57

- $59 \%$ of the consumers give their opinion in favor of easily available products which may not possess the ecofriendly characteristics

Table II: Purchasing Decisions of Costumers

\begin{tabular}{|l|l|c|c|c|c|c|c|}
\hline S1 & Factors & $\begin{array}{c}\text { Favor } \\
\text { (\% age) }\end{array}$ & $\begin{array}{l}\text { Neutral } \\
\text { (\% age) }\end{array}$ & $\begin{array}{c}\text { Against } \\
\text { (\% age) }\end{array}$ & Mean & $\begin{array}{c}\text { Standard } \\
\text { Deviation }\end{array}$ & $\begin{array}{c}\text { Standard } \\
\text { Error }\end{array}$ \\
\hline $\mathbf{1}$ & $\begin{array}{l}\text { Low brand value but } \\
\text { eco-friendly products }\end{array}$ & 74 & 11 & 15 & 5.54 & 2.1 & .136 \\
\hline $\mathbf{2}$ & $\begin{array}{l}\text { High brand value but not } \\
\text { eco-friendly products }\end{array}$ & 70 & 6 & 24 & 5.25 & 2.45 & .158 \\
\hline $\mathbf{3}$ & $\begin{array}{l}\text { Not widely available but } \\
\text { eco-friendly products }\end{array}$ & 88 & 6 & 6 & 6.29 & 1.57 & .101 \\
\hline $\mathbf{4}$ & $\begin{array}{l}\text { Widely available but not } \\
\text { eco-friendly products }\end{array}$ & 59 & 9 & 32 & 4.76 & 2.55 & .165 \\
\hline
\end{tabular}


Table III: Correlation between Consumer behavior \& Purchasing Decisions of the Customer

\begin{tabular}{|c|c|c|c|c|c|}
\hline S1 & $\begin{array}{l}\text { Components of Marketing Mix- } \\
\text { Environmental Marketing }\end{array}$ & $\begin{array}{l}\text { Low brand value } \\
\text { but eco-friendly } \\
\text { products }\end{array}$ & $\begin{array}{l}\text { High brand value } \\
\text { but not eco- } \\
\text { friendly products }\end{array}$ & $\begin{array}{l}\text { Not widely } \\
\text { available but eco- } \\
\text { friendly products }\end{array}$ & $\begin{array}{l}\text { Widely available } \\
\text { but not eco- } \\
\text { friendly products }\end{array}$ \\
\hline 1 & Product: Priority to eco-friendly products & .114 & .172 & .107 & .101 \\
\hline 2 & $\begin{array}{l}\text { Price: Willingness to purchase } \\
\text { Green products at more price }\end{array}$ & .123 & .306 & .092 & .153 \\
\hline 3 & $\begin{array}{l}\text { Place: Choose those places which } \\
\text { are environmental friendly }\end{array}$ & .179 & .007 & .047 & .087 \\
\hline 4 & $\begin{array}{l}\text { Promotion: Prefer promotion } \\
\text { campaign that protect environment }\end{array}$ & .118 & 225 & .222 & 99 \\
\hline
\end{tabular}

\section{ReAson for EnVIRONMENTAL MARKETING}

Due to the following reasons companies are bound to adopt environmental marketing strategy:

Competitor Strategy: A Number of companies now taking the steps to produce eco-friendly products. Therefore, the organizations also adopt the environmental marketing to compete in the global market.

Cost Effectiveness: A by-product of one enterprise used as the raw material in another enterprise to produce the green -products. By the result of which cost of production of the Industries are going to reduce.

Government Regulations: Now the government has also formulated a number of rules \& regulations for the industries to reduce pollution level and to protect the environment. It is mandatory for the organizations to follow those rules \& regulations.

Opportunity: Health-conscious consumers prefer the green products. Therefore, Entrepreneurs see environmental marketing as bringing an opportunity for them to draw the attention of the customers towards their product.

Social Obligation: Entrepreneurs can get a huge profit by doing business in the society. Therefore, it is their moral responsibility to protect the social environment by practicing \& implementing environmental marketing.

Consumer Awareness: Consumer awareness towards green product has tremendously increased. Customers are now ready to purchase the green products even at the more prices.

Resources Optimization: Resources are always limited \& human wants are unlimited. By the help of environmental marketing, we can take the steps for resource optimization.

\section{ENVIRONMENTAL MARKETING: INITIATIVES BY INDUSTRIES}

Over the past few years, some segments in India have seen eco-friendly initiatives by industries. Partially, to differentiate their contributions in a competitive environment and partly to take benefit of the price premium, many companies have started offering branded products in several classes. Some of these are mentioned below:

- Environment Management Policy of HCL is named as HCL eco-Safe

- CFL is produced by Philips Lights

- Proctor and Gamble has introduced refills for its cleaners and detergents in Europe that comes in throwaway packs.

- McDonald's restaurants used recycled paper to prepare its napkins \& bags

- Amway claims that its goods are eco-friendly.

- Tata Steel, HLL, Jindal Vijaynagar Steel, Essar Power and Gujarat Fluro-chemicals Ltd. etc have got clearance to undertake specifically designed projects in order to gain benefits from carbon trading (Kyoto Protocol).

- Coca-Cola is able to save 68 million pound/year by pumping syrup directly from tank instead of using plastic tubes.

- New Surf Excel (Do Bucket Paani... Ab Rozana Hai Bachana) which forms lesser froth but is as active as before, thus decreasing water consumption.

- Green building drive, headed by the Confederation of Indian Industry (CII) - Godrej Green business Center.

- Barauni refinery of IOC is able to restrict air and water pollutants in number of ways.

- Lifebuoy (Unilever in India- Soap) encouraged teenagers in advertisement to clean their roads. Lifebuoy protect them from germs.

- Badarpur Thermal Power Station of NTPC in Delhi is taking steps to reduce air and water pollution by devising methods to utilize coal-ash.

- The Hewlett-Packard Company publicised strategies to bring energy-saving goods throughout the world.

- Intel India is performing plantation and cultivation as activity towards corporate social responsibility.

- ITC's Watershed Development project carries water to nearly 35,000 hectares of dry lands.

- Recycling used products also acts as a step towards minimizing wastes.

- ITC's Bhadrachalam Paper unit has capitalised Rs. 500 crore on technology that makes the unit chlorine free. 


\section{CONCLUSION}

According to Dr Philip Kotler (Father of Marketing Management), it is quite impossible to satisfy the customer. But we have to take continuous steps in order to delight them. Obliviously environment marketing is one of the best ways for that. A wise entrepreneur never tries to convince the customer, always tries to involve the customer for the marketing of his product. By the help of environmental marketing Industrialists are not only able to protect the environment but also they are able to draw the attention of the consumer. Environmental marketing is not an option. It is the compulsion in the $21^{\text {st }}$ century for all the successful entrepreneurs.

\section{REFERENCES}

Chopra, S. Lakshmi (2007), Turning Over a New Leaf, Indian Management, Vol. 64, April, 2007.

Crane, A. (2000), "Facing the Blacklash: Green Marketing and Strategic re-orientation in the 1990s", Journal of Strategic Marketing, Vol. 8, No. 3, pp.277-96.

Davis, Joel J. (1992), “Ethics and Green Marketing”, Journal of Business Ethics Vol. 11, No. 2, pp. 81-87.

Ghosh, Amitabha (2008), Green Marketing Strategies; ICFAI Publishing.

Grant, John (2008), The Green Marketing Manifesto, John Wiley \& Sons Publications.

Green or not Green? That is the Question, Media Week, April 18, 2010.

How not to get Green Washed, Globe and Mail, April 18, 2010.

Jain, Sanjay (2004), "Green Marketing: An Attitudinal and Behaviourial Analysis of Indian Consumers", Global Business Review, Vol. 5, No. 2, pp. 187-205.

Nagaraju, D. B., \&Thejaswini, H. D. (2014). Consumers \' perception analysis-market awareness towards ecofriendly fmcg products-a case study of mysore district. IOSR Journal of Business and Management, 16, 64-71. Retrieved from http:/ /iosrjournals.org/iosr-jbm/papers/vol16-issue4/version-5/i016456471.pdf

Rahbar, E., \& Wahid, N. A. (2011).Investigation of green marketing tools' effect on consumers' purchase behavior. Business strategy series, 12(2), 73-83.doi:10.1108/17515631111114877

Rajeshkumar, M. L. (2012). An overview of green marketing. Naamex International Journal of Management Research, 2, 128-136. Retrieved from http://www.namexijmr.com/pdf/archives_jan_june_2012/namex\%20ijmr\%20\%20abstract \%20and\%20paper \%2014.pdf

Responsibility (n. d.). Retrieved from the Starbucks company website: http://www.starbucks.com/responsibility

Saini, B. (2013). Green marketing and its impact on consumer buying behavior. International Journal of Engineering Science Invention, 2, 61-64. Retrieved from http:/ / www.ijesi.org/papers/Vol\%202(12)/Versi on-2/K021202061064.pdf

Suki, N. M. (2013). Green Awareness effects on consumer's purchasing decision: Some insights from malaysia. Green awareness effect, 9, 50-63. Retrieved from http://ijaps.usm.my/wp-content/uploads/2013/07/art3.pdf

Vandhana, R., Karpagavalli, G., \& Ravi, D. A. (2013).Green Marketing- A tool for sustainable development. Global research analysis, 2, 133-135. Retrieved from http://theglobaljournals.com/gra/file. php?val=december_2013_1387275869_75066_42.pdf

Yakup, D., \& Sevil, z. (2011).A theoretical approach to concept of green marketing assits. Interdisciplinary Journal of Contemporary Research in Business, 3(2), 1808-1814.

Yazdanifard, R.,\& Mercy, I. E. (2011).The impact of green marketing on customer satisfaction and environmental safety.2011 International Conference on Computer Communication and Management, 5, 637-641. Retrieved from file:/ / c:/users/se7en/downloads/0912f50e642f52da0b000000\%20(5).pdf

Website

http:/ /bx.businessweek.com/green-marketing/news/

http://www.business.gov

http://www.businessgreen.com

http:/ / www.greenmarketing.com/ 